\title{
JURNALISTIK DAN MINAT MAHASISIWA (Studi Pengaruh Mata Kuliah Jurnalistik Terhadap Minat Mahasiswa KPI IAIDA Blokagung Banyuwangi Menjadi Jurnalis)
}

\author{
Abdi Fauji Hadiono \\ Institut Agama Islam Darussalam (IAIDA) Banyuwangi \\ Email: abdifauji777@gmail.com
}

\begin{abstract}
This research is focused to analyze the influence of journalism subjects on student interest of IAIDA KPI Blokagung Banyuwangi become Journalist. With the population as well as samples of students of IAIDA KPI Blokagung Banywangi force of 2014 which amounted to 20 students. The type of quantitative research that uses the ethical approach, in the sense that researchers collect data by first establishing the concept as the related variables derived from existing theory chosen by the researcher. Only from predetermined indicators are made questionnaires answer options and scores. In this research, the data collection by spreading the questionnaires to the IAIDA KPI IAIDA Blokagung Banyuwangi class of 2014. After analyzing the data collected, the researcher found that there is influence between journalistic subjects $(X)$ on the interest of IAIDA KPI student BLokagung Banyuwangi become a journalist by using correlation test Pearson Product Moment is quite strong. The conclusion is: "There is a significant influence between Journalism Subjects to Student Interest KPI IAIDA Blokagung Banyuwangi become Journalist
\end{abstract}

\section{Keywords: Journalism, Journalists, Students, Interests}

\begin{abstract}
Abstrak
Penelitian ini difokuskan untuk menganalisis pengaruh mata kuliah jurnalistik terhadap minat mahasiswa KPI IAIDA Blokagung Banyuwangi menjadi Jurnalis. Dengan populasi sekaligus sampelnya yaitu mahasiswa KPI IAIDA Blokagung Banywangi angkatan 2014 yang berjumlah 20 mahasiswa. Jenis penelitian kuantitatif yang menggunakan pendekatan etik, dalam arti bahwa peneliti mengumpulkan data dengan menetapkan terlebih dahulu konsep sebagai variabel-variabel yang berhubungan yang berasal dari teori yang sudah ada yang dipilih oleh peneliti. Hanya dari indikator yang telah ditetapkan tersebut dibuat angket, pilihan jawaban dan skor-skornya. Dalam penelitian ini, pengumpulan datanya dengan menyebarkan angket kepada mahasiswa KPI IAIDA Blokagung Banyuwangi angkatan 2014. Setelah melakukan analisa data yang dikumpulkan, peneliti menemukan bahwa ada pengaruh antara mata kuliah jurnalistik $(X)$ terhadap minat mahasiswa KPI IAIDA Blokagung Banyuwangi menjadi jurnalis dengan menggunakan uji korelasi Pearson Product Moment tergolong kuat. Kesimpulannya adalah: "Ada pengaruh yang signifikan antara Mata Kuliah Jurnalistik Terhadap Minat Mahasiswa KPI IAIDA Blokagung Banyuwangi menjadi Jurnalis.
\end{abstract}

Kata Kunci : Jurnalistik, Jurnalis, Mahasiswa, Minat 


\section{A. Latar Belakang}

Yayasan Pondok Pesantrren Darussalam Blokagung Banyuwangi yang dari tahun ke tahun perkembanganya semakin pesat bukan berarti tanpa masalah terutama menyangkut daya tampung akademis. Pada tanggal 17 Juni 2001 pendidikan Tinggi Bernama Sekolah Tinggi Agama Islam Darussalam (STAIDA) dibawah asuhan Yayasan Pondok Pesantren Darussalam Blokagung Banyuwangi telah dibuka dan diresmikan oleh Menristek RI (Bpk. DR H. AS Hikam), disaksikan oleh Bupati Banyuwangi (Ir. Syamsul Hadi) dan Pengasuh Pondok Pesantren Darussalam Blokagung Banyuwangi (KH. Ahmad Hisyam Syafaat).

Dengan tekad yang bulat dan memenuhi permintaan dari beberapa alumni dan seluruh steakholder, maka sejak bulan november 2014 STAIDA Beralih status menjadi IAIDA. Dalam sistem penyelenggaraan pendidikan, IAIDA terbagi menjadi 3 Fakultas dan 8 Program Studi diantaranya yaitu Fakultas Tarbiyah dan Keguruan yang terdiri 4 program studi yaitu Manajemen pendidikan islam (MPI), Pendidikan bahasa arab (PBA), Tadris Bahasa Inggris (BIG) Dan Tadris Bahasa Indonesia (BIND), Kemudian ada Fakultas Ekonomi dan Bisnis Islam yang terdiri dari 2 program studi yaitu Ekonomi Syariah (ESY), Perbankan syariah (PSY), dan Fakultas Dakwah dan komunikasi Islam yang terdiri dari 2 program studi yaitu Komunikasi dan penyiaran islam (KPI), Bimbingan dan konseling Islam (BKI) (PEDOMAN AKADEMIK IAIDA 2016)

Perguruan tinggi sebagai penghasil tenaga kerja terampil dan tenaga ahli yang berkarakter serta inovasi yang memiliki daya saing dalam dan luar negeri. Perguruan Tinggi adalah jenjang pendidikan setelah pendidikan menengah yang mencakup program diploma, sarjana, program magister, program doktor, dan program profesi, serta program spesialis yang diselenggarakan oleh lembaga pendidikan tinggi berdasarkan kebudayaan bangsa indonesia. Keberadaannya di dalam kehidupan berbangsa dan bernegara berperan sangat penting melalui adanya penerapan Tri Dharma Perguruan Tinggi, yaitu kewajiban perguruan tinggi untuk menyelenggarakan pendidikan dan pengajaran, penelitian dan pengembangan serta pengabdian kepada masyarakat.

1. Pendidikan dan Pengajaran adalah usaha sadar dan terencana untuk mewujudkan suasana belajar dan proses pembelajaran agar peserta didik 
secara aktif mengembangkan potensi dirinya untuk memiliki kekuatan spiritual keagamaan, pengendalian diri, kepribadian, kecerdasan, akhlaq mulia, serta ketrampilan yang diperlukan dirinya, masyarakat, bangsa dan negara.

2. Penelitiaan adalah kegiatan yang dilakukan menurut kaidah dan metode ilmiah secara sitematis untuk memperoleh informasi, data, dan keterangan yang berkaitan dengan pemahaman dan atau pengujian suatu cabang ilmu pengetahuan dan teknologi.

3. Pengabdian Kepada Masyarakat adalah kegiatan civitas akademika yang memanfaatkan ilmu pengetahuan dan teknologi untuk memajukan kesejahteraan masyarakat dan mencerdaskan kehidupan bangsa.

Pendididikan dalam hal ini yang dimaksud adalah proses komunikasi secara primer yaitu proses penyampaian pikiran oleh komunikator kepada komunikan dengan menggunakan suatu lambang sebagai media atau saluran, lambang ini umumnya bahasa, tetapi dalam situasi-situasi komunikasi tertentu lambaglambang yang dipergunakan dapat berupa kial (gesture) yakni gerak anggota tubuh, gambar, warna, dan lain sebagainya (Onong Uchjana Effendy, 2003:33)

Komunikasi dan Penyiaran Islam (KPI) adalah Salah satu Program studi yang ada dibawah naungan Fakultas Dakwah dan Komunikasi Islam dengan beberapa standart komptensi yang dimiliki Progran Studi Komunikasi dan Penyiaran Islam yaitu diantaranya :

1. Kompetensi dasar yaitu kompetensi yang dimiliki oleh setiap mahasisaw sebagai dasar bagi kompetensi utama, kompetensi pendukung dan kompetensi lainya. Dalam kompetensi dasar ini mahasiswa diharapkan memiliki pengetahuan secara komprehensisif tentang ajaran dan ilmu-ilmu agama ,memiliki pengetahuan tentang persoalan kemasyarakatan dan kenegaraan, memiliki kemampuan berbahasa, memiliki komitmen keislaman keindonesiaan dan keilmuan.

2. Kompetensi utama yaitu kompetensi yang dimiliki oleh setiap mahasiswa sesudah menyelesaikan pendidikanya di suatu program studi tertentu.

Selain kompetensi dasar dan kompetensi utama yang ada pada Prodi KPI juga ada kompetensi pendukung yang diharapkan dapat membantu kompetensi utama 
selain keilmuan umum dan islami yaitu diantaranya Kompetensi media Cetak dakwah, dimana mahasiswa terampil menulis karya Jurnalistik serta mengelola media cetak dan Kompetensi Media Radio dan Televisi dimana mahasiswa terampil dalam merancang dan melakukan program dakwah melalui Radio dan Televisi. Dua kompetensi tersebut dapat menunjang skill dan bisa dijadikan bekal didunia kerja. Adapun kompetensi lainya yaitu kompetensi yang dianggap perlu dimiliki mahasiswa sebagai bekal mengabdi di masyarakat (Buku Kurikulum Tingkat Satuan Pendidikan Tinggi Komunikasi dan Penyiaran Islam). Studi ilmu komunikasi terintegrasi dengan penyiaran dan dakwah Islam, dengan berbagai Struktur keillmuan yang ada di dalamnya, diantaranya ilmu dakwah, Materi dakwah islam, metodologi dakwah, jurnalistik, ilmu Komunikasi, fotografi dan struktur keilmuan KPI yang lainya. Prodi KPI ini bertujuan untuk melahirkan sarjana yang memiliki kemampuan Terampil memanfaatkan teknologi informasi dan komunikasi dalam kepenyiaran islam, terampil merancang dan melaksanakan dakwah melalui media cetak, terampil merancang dan melaksanakn dakwah melalui media elektronik (radio, televisi, internet).

Dalam mata kuliah Jurnalistik yang diberiakan pada mahasiswa Prodi Komunikasi dan penyiaran Islam (KPI) Fakultas Dakwah dan Komunikasi Islam Institut Agama Islam Darussalam Blokagung Banyuwangi tentunya mendukung mahasiswa untuk memudahkan bergerak di bidang komunikasi dan industri media yaitu sebagai jurnalis, baik sebagai jurnalis media cetak dan media elektronik, Berdasarkan latar belakang dalam penelitian diatas, dan mahasiswa yang sebagian besar adalah santri serta banyak berkecimpung di dunia tulisan baik dalam media bulletin pondok maupun buletin kampus, menjadi salah satu alasan penulis untuk melakukan penelitian tentang adakah pengaruh dari mata kuliah Junalistik terhadap minat Mahasiswa KPI IAIDA Blokagung Banyuwangi untuk menjadi jurnalis.

\section{B. Rumusan Masalah}

Dari latar belakang di atas maka dapat diambil sebuah rumusan masalah sebagai berikut: Adakah Pengaruh Mata Kuliah Jurnalistik terhadap minat mahasiswa Komunikasi dan Penyiaran Islam Fakultas Dakwah dan komunikasi Islam IAIDA Blokagung Banyuwangi Menjadi Jurnalis? 


\section{Tujuan Penelitian}

Adapun tujuan dari penelitian ini adalah sebagai berikut: Untuk mengetahui Adakah Pengaruh Mata Kuliah Jurnalistik terhadap minat mahasiswa Komunikasi dan Penyiaran Islam Fakultas Dakwah dan komunikasi Islam IAIDA Blokagung Banyuwangi Menjadi Jurnalis.

\section{Kegunaan Penelitian}

1. Kegunaan Teoritis

Jika ilmu jurnalistik dimiliki oleh mahasiswa, maka mahasiswa memiliki kemampuan tentang jurnalistik.

2. Kegunaan Praktis

Jika ilmu jurnalistik diimplementasikan oleh mahasiswa, maka mahasiswa menguasai dan memiliki kemampuan menjadi jurnalis.

\section{E. Ruang Lingkup Penelitian}

Untuk membatasi lingkup penelitian, maka peneliti memfokuskan penelitian ini pada adakah pengaruh mata kuliah jurnalistik terhadap minat mahasiswa KPI IAIDA Blokagung Banyuwangi untuk menjadi jurnalis, dan penelitian ini hanya meneliti mahasiswa KPI IAIDA angkatan 2014 yang telah mendapatkan mata kuliah jurnalistik.

\section{F. Kajian Pustaka}

\section{Mata Kuliah Jurnalistik}

Mata Kuliah Jurnalistik adalah Mata kuliah yang menjelaskan tentang dasar dasar jurnalistik dalam pers, dengan standart kompetensi dapat memahami teori dasar Jurnalistik. Adapun kompetensi dalam mata kuliah jurnalistik yaitu mahasiswa bisa menggunakan bahasa pers, dan memfiksasikan menjadi sebuah karya jurnalistik. Mata kuliah jurnalistik memiliki beberapa kompetensi dasar yaitu sebagai berikut:

a. Memahami konsep dasar jurnalistik dari aspek teoritis dan historistas dengan indikator mahasiswa dapat paham makna dasar jurnalistik, mahasiswa paham akan sejarah jurnalistik, dan mahasiswa mengetahui teori-teori jurnalistik. 
b. Memahami ragam dan jenis jurnalistik dengan indikator mahasiswa memahami macam-macam dan jenis jurnalistik, mahsiswa mengetahui karakteristik jurnalistik, mahasisiwa mampu membuat membuat karya jurnalistik sesuai dengan ragam dan jenisnya.

c. Memahami pelaku lembaga dan karya jurnalistik drngan indikator mahasiswa paham terhadap makna dan tugas jurnalis, mahasiswa mengetahui pada makna pers sebagai media jurnalistik, mahasiswa mampu memetakan karya-karya jurnalistik dan membuat karya jurnalistik.

Mata kuliah jurnalistik diberikan kepada mahasiswa yang mengambil Prodi KPI Fakultas Dakwah dan Komunikasi Islam yang didalamnya mencakup materi-meteri tentang :

a. Pengertian, bentuk dan fungsi jurnalistik

b. Ruang lingkup jurnalistik

c. Teori-teori jurnalistik

d. Macam;macam jurnalistik

e. Jenis-jenis jurnalistik

f. Karakteristik jurnalistik sesuai dengan macam dan jenisnya

g. Makna, tugas dan fungsi wartawan dalam dunia jurnalistik

h. Sejarah pers dan teori-teori pers

i. Model dan modul karya jurnalistik ( cetak dan elektronik)

Dari mata kuliah Jurnalistik yang diberikan pada mahasiswa Prodi KPI Fallultas Dakwah dan Komunikasi Islam IAIDA menjadi penting untuk Mahasiswa KPI selain sebagai keilmuan juga sebagai bekal ketika bergerak di bidang industri media khususya jurnalis, baik sebagai jurnalis media cetak maupun elektronik. Melihat latar belakang dari Mahasiswa yang Sebagian besar adalah Santri dan sudah biasa berkecimpung dengan dunia tulisan baik dalam media buletin pondok maupun bulletin kampus, juga menjadi suatu pendorong mahasiswa untuk menjadi seorang jurnalis nantinya (Buku Kurikulum Tingkat Satuan Pendidikan Tinggi).

\section{Minat Mahasiswa Menjadi Jurnalis}


Minat artinya perhatian, kesukaan atau kecenderungan hati kepada suatu keinginan dimana seseorang menaruh perhatian terhadap sesuatu yang disertai keinginan mengetahui, mempelajari dan membuktikan lebih lanjut.

Minat yang penulis maksud dalam penelitian ini adalah suatu kecenderungan individu dimana seseorang menaruh perhatian kepada sesuatu disertai dengan keinginan mengetahui, mempelajari dan membuktikan lebih lanjut, kemudian ia merasa tertarik berkecimpung dalam bidang itu. (Winkel W.S., 1986:30)

Pada dasarnya, minat dalam diri seseorang terdapat unsur-unsur sebagai berikut:

a. Terjadinya sesuatu hal yang menarik

b. Terdapatnya kontras yaitu antara hal yang satu dengan hal yang lainnya sehingga apa yang menonjol itu menimbulkan perhatian

c. Terdapatnya harapan akan menjadi keuntungan atau mungkin gangguan dari hal yang dimaksud.

\section{Mahasiswa}

Mahasiswa adalah seseorang yang sedang dalam proses menimba ilmu ataupun belajar dan terdaftar sedang menjalani pendidikan pada satu bentuk perguruan tinggi yang terdiri dari akademik, politeknik, sekolah tinggi, institut dan universitas (Hartaji, 2012:5).

Menurut KBBI (Kamus Besar Bahasa Indoneia) Mahasiswa didefinisikan sebagai seorang yang belajar di perguruan tinggi (Kamus Bahasa Indonesia Online, kbbi.web.id).

Mahasiswa juga dikatakan sebagai suatu kelompok dalam masyarakat yang memperoleh statusnya karena ikatan dengan perguruan tinggi. Mahasiswa juga merupakan calon intelektual atau cendekiawan muda dalam suatu lapisan masyarakat yang sering kali syarat dengan berbagai predikat (Caly, Sadili, 2012:1).

Di dalam struktur pendidikan di Indonesia mahasiswa memegang status pendidikan tertinggi diantara yang lain. Menurut Sarwono Mahasiswa adalah setiap orang yang secara terdaftar untuk mengikuti pelajaran di sebuah perguuan tinggi dengan batasan umur sekitar 18-30 tahun. Mahasiswa 
merupakan suatu kelompok dalammasyarakat yang memperoleh statusnya, karena adanya ikatan dengan suatu perguruan tinggi. Menurut Knopfemacher, Mahasiswa adalah seseorang calon sarjana yang dalam keterlibatanya dengan perguruan tinggi yang di didik dan diharapkan untuk menjadi calon-calon yang intelektual.

\section{Jurnalis}

a. Tinjauan Umum Tentang Jurnalis

Istilah jurnalis dari kata jurnalistik yang berasal dari bahasa Perancis: "Journal", berarti catatan harian. Jurnalistik berkaitan dengan catatan harian yang dipublikasikan kepada masyarakat dan terbit secara teratur (YS. Gunadi, 1998: 64). "Journal" atau "De jour" berarti hari, dimana segala berita atau warta sehari itu termuat dalam lembaran yang tercetak. Dalam perkembangannya istilah jurnalistik disenadakan dengan pers atau jurnalis (Dja'far Assegaf, 1991: 10).

Jurnalis atau wartawan adalah seseorang yang bekerja dalam bidang jurnalisme atau peliputan sebuah objek artikel tertentu, misalnya sebuah berita atau kejadian, sebuah tempat, sebuah kondisi alam / lingkungan, profil seseorang, tanggapan seseorang, atau pembahasan-pembahasan yang lain.

Hasil liputan oleh seorang jurnalis ini nantinya dipublish (disampaikan ke masyarakat luas) melalui media massa yang bersangkutan, baik media massa elektronik, maupun media massa cetak.

1) Media massa elektronik contohnya: televisi, radio, internet.

2) Media massa cetak contohnya: koran, majalah, tabloid.

b. Beberapa Posisi dalam Dunia Jurnalis:

1) Writer: Bertugas menulis liputan (merekam secara audio sebelum kemudian ditulis ulang)

2) Fotografer: Bertugas merekam video liputan

3) Reporter: Bertugas menyampaikan isi liputan secara live atau tidak, bisa dalam bentuk gambar dan suara di depan kamera 
video, bisa juga dalam bentuk suara saja di depan alat perekam suara atau alat live suara.

4) Editor: Bertugas mengedit hasil liputan wartawan sesuai dengan konsep pemberitaan sebuah perusahaan media.

5) Desainer Grafis: Bertugas mengatur atau membuat desain grafis, seperti sampul majalah, lay out / desain setiap halaman, membuat ilustrasi.

c. Job Description Jurnalis

1) Menghadiri konferensi pers, rapat redaksi, dan acara lainnya.

2) Melakukan wawancara narasumber secara langsung atau melalui telepon jika terpaksa.

3) Membuat rilis berita.

4) Mencatat hasil wawancara tersebut di steno atau merekamnya di tape.

5) Menyusun transkrip wawancara.

6) Menulis naskah berita sesuai dengan transkrip wawancara.

7) Memelihara kontak dan menjaga hubungan baik dengan narasumber.

d. Berita dan Proses Kerja Jurnalis

Secara umum proses kerja jurnalis terdiri dari dua tahap, yaitu peliputan dan reportase, penulisan berita dan editing, namun sebelumnya perlu dibahas sedikit tentang apa itu berita, sebab berita adalah inti dari kegiatan jurnalistik yang akan dikerjakan oleh jurnalis, bahkan lebih dari $90 \%$ isi media cetak adalah berita yang disediakan oleh jurnalis. Meskipun untuk memberikan pengertian mengenai berita tidaklah mudah, tetaplah perlu untuk mencoba mencari pengertian yang tepat, pengertian dan batasan mengenai berita tidaklah mudah, tetaplah perlu untuk mencoba mencari pengertian yang tepat, pengertian dan batasan mengenai berita merupakan bekal bagi jurnalis karena dengan pengertian yang dimiliki tentang berita akan sangat menentukan tingkat kemampuan dan profesionalitas kewartawanan dalam menilai sesuatu sebagai berita. 
e. Syarat-syarat Menjadi Jurnalis yang Baik

1) Pengalaman, adalah hal-hal atau kejadian-kejadian yang dialami seseorang. Jurnalis akan banyak belajar menulis berita yang baik dengan mengalami sendiri bagaimana caranya membuat berita.

2) Perasaan ingin tahu, seorang jurnalis meliput sebuah berita dan peristiwa, pasti rasa ingin tahu jurnalis muncul dengan segera mengeluarkan pertanyaan-pertanyaan yang akan menjawab kenapa peristiwa itu terjadi dan apa yang sebenarnya terjadi.

3) Daya khayal, daya khayal atau imajinasi dalam pemberitaan tergantung dari tinjauan ke depan maupun ke belakang. Maksdunya disini adalah pers bukan saja harus mengungkapkan peristiwaperistiwa yang terjadi secara aktual.

4) Pengetahuan, seorang jurnalis yang tidak menguasai paling sedikitnya ilmu pengetahuan kemasyarakatan akan sulit mempersepsikan dinamika yang dialami masyarakat Indonesia. (Muhammad Budyatna, 2014: 78-82).

\section{G. Hipotesis}

Hipotesis adalah sarana penelitian ilmiah yang penting dan tidak bisa ditinggalkan karena merupakan instrumen kerja dari teori (Singarimbun, 1995:43). Hipotesis adalah kesimpulan yang masih belum final, dalam arti masih harus dibuktikan atau diuji kebenarannya (Nawawi, 2001: 44). Hipotesis yang diajukan dalam penelitian ini adalah sebagai berikut:

Ha: Terdapat pengaruh mata kuliah jurnalistik terhadap minat mahasiswa KPI IAIDA Blokagung Banyuwangi menjadi jurnalis.

Ho: Tidak terdapat pengaruh mata kuliah jurnalistik terhadap minat mahasiswa KPI IAIDA Blokagung Banyuwangi menjadi jurnalis.

\section{H. Metode Penelitian}

\section{Lokasi Penelitian}

Penelitian ini dilakukan di kampus Institut Agama Islam Darussalam (IAIDA) Blokagung Banyuwangi dengan objek penelitiannya adalah mahasiswa Progam Studi Komunikasi dan Penyiaran Islam (KPI) Fakultas 
Dakwah dan Komunikasi Islam angkatan 2014 yang telah mendapatkan mata kuliah Jurnalistik.

\section{Populasi dan Sampel Penelitian}

Dalam penelitian ini populasi adalah seluruh mahasiswa KPI IAIDA Blokagung Banyuwangi angkatan 2014 yang berjumlah 20 mahasiswa yang mempunyai ciri dan karakteristik yang sama yaitu sama-sama sebagai mahasiswa KPI IAIDA, sama-sama angkatan 2014, sama-sama telah mendapatkan mata kuliah jurnalistik.

Dalam penelitian ini teknik sampling yang digunakan adalah nonprobability sampling dengan jenis sampling jenuh yaitu seluruh mahasiswa KPI IAIDA Blokagung Banyuwangi angkatan 2014 yang berjumlah 20 mahasiswa. Sampling jenuh adalah teknik penentuan sampel bila semua anggota populasi digunakan sebagai sampel (Sugiyono, 2006:61).

\section{Teknik Pengumpulan Data}

Pengumpulan data dalam penelitian ini menggunakan metode-metode yang disesuaikan dengan masalah yang diteliti atau dianalisa. Dalam hal ini digunakan beberapa metode pengumpulan data yaitu, metode dokumentasi dan angket.

a. Metode Dokumentasi

b. Metode Angket

\section{Teknik Analisis Data}

Instrumen penelitian yang digunakan dalam penelitian ini adalah angket dimana para responden mengisi angket dengan memberi tanda silang ( $\times$ ) sebagai penanda jawaban yang dipilih pada daftar pertanyaan yang telah disediakan peneliti. Sebelum menyajikan data tentang pengaruh mata kuliah Jurnalistik terhadap minat mahasiswa KPI IAIDA Blokagung Banyuwangi menjadi Jurnalis, terlebih dahulu disajikan bagaimana pengambilan nilai terhadap pertanyaan-pertanyaan yang ada. Setiap butir pertanyaan dalam angket disediakan 4 kategori. Setiap jawaban dinyatakan dengan simbol. Untuk skornya dilakukan dengan simbol tersebut yang diubah kedalam angka. Hal ini dimaksudkan untuk mempermudah dalam perhitungan. Adapun ketentuannya sebagai berikut 
1. Jika responden menjawab a maka diberi skor : 4

2. Jika responden menjawab $b$ maka diberi skor $: 3$

3. Jika responden menjawab c maka diberi skor :2

4. Jika responden menjawab d maka diberi skor : 1

(Arikunto, 2006:160)

Teknik analisis data yang digunakan dalam penelitian ini adalah korelasi Pearson Product Moment dengan dua variabel.

Korelasi Pearson Product Moment merupakan korelasi yang dikemukakan oleh Karl Pearson Tahun 1900. Kegunaannya untuk mengetahui derajat hubungan dan kontribusi variabel bebas (independent) dengan variabel terikat (dependent).

Teknik analisis korelasi Pearson Produk Moment termasuk teknik statistik parametrik yang menggunakan data interval dan ratio dengan persyaratan tertentu. Misalnya: data dipilih secara acak (random, datanya berdistribusi normal; data yang dihubungkan berpola linier; dan data yang dihubungkan mempunyai pasangan yang sama sesuai dengan subjek yang sama. Kalau salah satu tidak terpenuhi persyaratan tersebut analisis korelasi tidak dapat dilakukan (Riduwan, 2015: 81)

Adapun rumus korelasi Pearson Product Moment adalah sebagai berikut:

$$
r_{X Y}=\frac{n\left(\sum x y\right)-\left(\sum x\right)\left(\sum y\right)}{\sqrt{\left[n \sum x^{2}-\left(\sum x\right)^{2}\right]\left[n \sum y^{2}-\left(\sum y\right)^{2}\right]}}
$$

Keterangan:

$\mathrm{r} \quad$ : Angka indeks korelasi

$\mathrm{x} \quad$ : Hasil angket dengan responden

y : Hasil interview dengan responden

$\sum x y \quad$ : Jumlah hasil perkalian skor $x$ dan $y$

n : Jumlah sampel penelitian

(Riduwan, 2015: 80)

Korelasi PPM dilambangkan (r) dengan ketentuan nilai $r$ tidak lebih dari harga $(-1 \leq \mathrm{r} \leq+1)$. Apabila nilai $\mathrm{r}=-1$ artinya korelasinya negatif sempurna; $r=0$ artinya tidak ada korelasi; dan $r=1$ berarti korelasinya sangat 
kuat. Sedangkan arti harga $\mathrm{r}$ akan dikonsultasikan dengan Tabel interpretasi Nilai r sebagai berikut.

Tabel 1. Interpretasi Koefisien Korelasi Nilai r

\begin{tabular}{|c|c|}
\hline Interval Koefisien & Tingkat hubungan \\
\hline $0,80-1,00$ & Sangat Kuat \\
\hline $0,60-0,799$ & Kuat \\
\hline $0,40-0,559$ & Cukup Kuat \\
\hline $0,20-0,399$ & Rendah \\
\hline $0,00-0,199$ & Sangat Rendah \\
\hline
\end{tabular}

(Riduwan, 2015:81)

Selanjutnya untuk menyatakan besar kecilnya sumbangan variabel $\mathrm{X}$ terhadap $\mathrm{Y}$ dapat ditentukan dengan rumus koefisien diterminan sebagai berikut.

$$
K P=r^{2} \times 100 \%
$$

Dimana :

$$
\begin{array}{ll}
\mathrm{KP} & =\text { Nilai Koefisien Diterminan } \\
\mathrm{R} & =\text { Nilai Koefisien Korelasi }
\end{array}
$$

Pengujian lanjutan yaitu uji signifikansi yang berfungsi apabila peneliti ingin mencari makna hubungan variabel $\mathrm{X}$ terhadap $\mathrm{Y}$, maka hasil korelasi Pearson Product Moment tersebut diuji dengan uji signifikansi dengan rumus:

$$
t_{\text {hitung }}=\frac{r \sqrt{n-2}}{\sqrt{1-r^{2}}}
$$

Dimana:

$$
\begin{array}{ll}
\mathrm{T}_{\text {hitung }} & =\text { Nilai } \mathrm{t} \\
\mathrm{r} & =\text { Nilai Koefisien Korelasi } \\
\mathrm{n} & =\text { Jumlah Sampel }
\end{array}
$$

(Riduwan, 2015: 81)

\section{Hasil Penelitian}

\section{Profil Prodi KPI Fakultas Dakwah dan Komunikasi Islam IAIDA}

Komunikasi dan Penyiaran Islam (KPI) adalah Salah satu Program studi yang ada dibawah naungan Fakultas Dakwah dan Komunikasi Islam. Berikut 
profil dari Prodi KPI Fakultas Dakwah dan Komunikasi Islam IAIDA Blokagung Banyuwangi

\section{Struktur Prodi KPI Fakultas Dakwah dan Komunikasi Islam}

\section{Gambar 1. Bagan Struktur Organisasi Fakultas Dakwah dan Komunikasi Islam IAIDA Blokagung Banyuwangi}

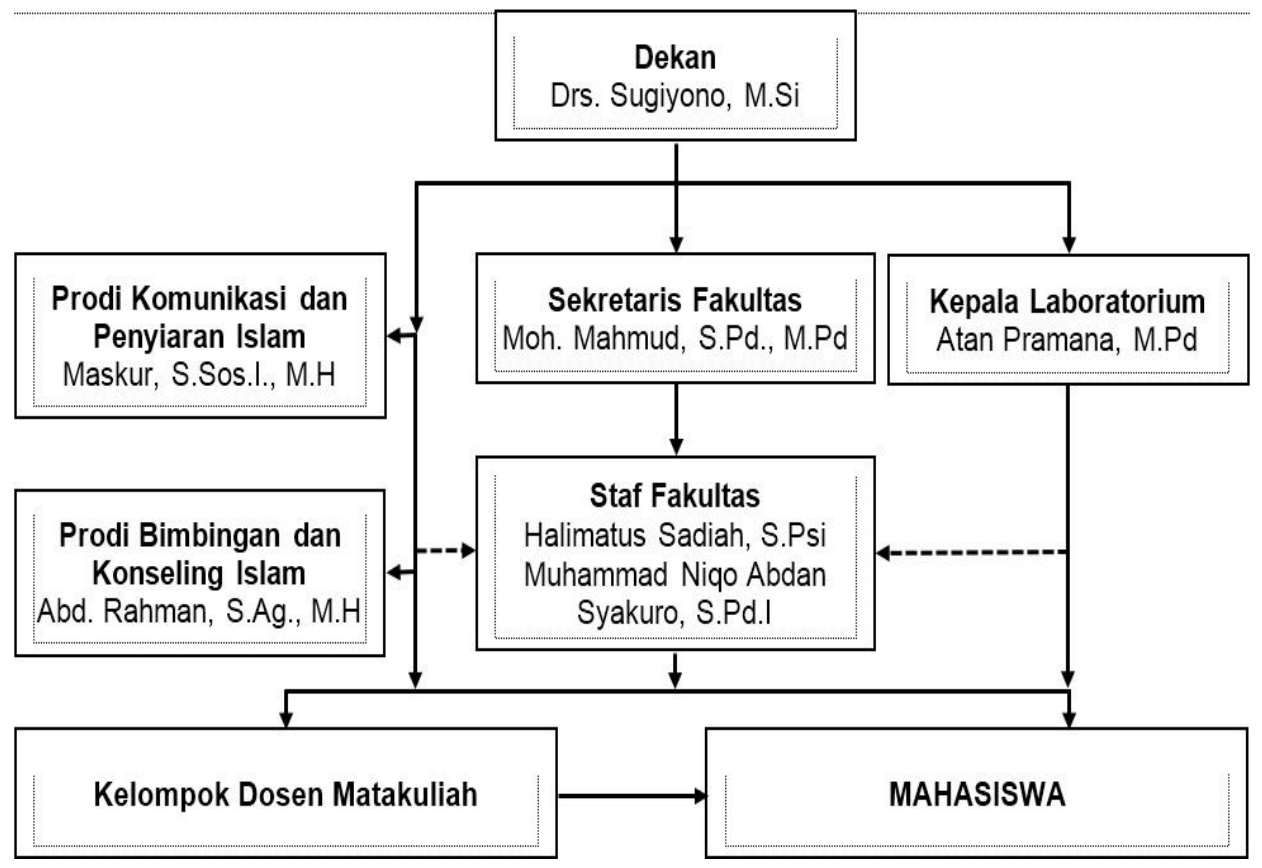

Ketua Prodi KPI memiliki peran penting dalam menjalankan fungsifungsi kepemimpinan yang efektif; baik operasional, organisasi, maupun publik dalam upaya mengkonsolidasikan semua potensi dan sumber daya yang ada di dalam Prodi, baik dosen, karyawan, laboratorium, perpustakaan, sarana fisik dan kurikulum, serta memudahkan akses informasi kepada semua pihak terkait dalam upaya meningkatkan kinerja Prodi KPI. Ketua Prodi KPI dibantu oleh sekertaris Program Studi lainnya secara aktif dan kontinyu melakukan pemantauan dan evaluasi efektivitas kurikulum yang ada untuk disesuaikan dengan kebutuhan pasar kontemporer. Kepemimpinan di Program Studi Komunikasi dan Penyiaran Islam (KPI) memiliki karakter operasional, organisasi, dan publik (Data Borang KPI 2017). 


\section{Analisis Data dan Pengujian Hipotesis}

\section{a. Secara deskriptif}

Untuk mengetahui apakah ada pengaruh antara Mata Kuliah Jurnalistik (X) Minat Mahasiswa KPI Menjadi Jurnalis (Y), kami menganalisisnya dengan menggunakan angket dengan data yang telah diterima dari responden.

\section{b. Secara Analitis}

Untuk mengetahui apakah ada pengaruh antara Mata Kuliah Jurnalistik (X) Minat Mahasiswa KPI Menjadi Jurnalis (Y), peneliti menganalisisnya dengan menggunakan Korelasi Pearson Product Moment yang rumus sebagai berikut:

Mencari $\mathrm{r}$ hitung dengan cara masukkan angka statistik dari tabel penolong dengan rumus:

$$
\begin{gathered}
r_{x y}=\frac{n\left(\sum x y\right)-\left(\sum x\right)\left(\sum y\right)}{\sqrt{\left[n \sum x^{2}-\left(\sum x\right)^{2}\right]\left[n \sum y^{2}-\left(\sum y\right)^{2}\right]}} \\
r_{x y}=\frac{20(8789)-(395)(443)}{\sqrt{\left[(20)(7889)-(395)^{2}\right]\left[(20)(9853)-(443)^{2}\right]}} \\
=\frac{795}{1193,023} \\
=0,67
\end{gathered}
$$

Berdasarkan rumus interval koefisien korelasi, nilai $r$ nya adalah 0,67 yang berarti memiliki tingkat hubungan yang kuat.

Mencari besarnya sumbangan (kontribusi) variabel $\mathrm{X}$ terhadap $\mathrm{Y}$ dengan rumus:

$$
K P=0,67^{2} x 100 \%=44,89 \%
$$

Menguji Signifikansi dengan rumus $t_{\text {hitung }}$ :

$$
\begin{gathered}
t_{\text {hitung }}=\frac{0,67 \sqrt{20-2}}{\sqrt{1-0,67^{2}}} \\
=\frac{2,843}{0,742}=3,831
\end{gathered}
$$


Kaidah Pengujian signifikansi dengan rumus:

Jika $t_{\text {hitung }} \geq t_{\text {tabel, }}$ maka tolak Ho artinya signifikan dan

$\mathrm{t}_{\text {hitung }} \leq \mathrm{t}_{\text {tabel, }}$, terima Ho artinya tidak signifikan

Berdasarkan perhitungan di atas, $\alpha=0,05$ dan $n=20$,

uji dua pihak;

$\mathrm{dk}=\mathrm{n}-2=20-2=18$, sehingga diperoleh $\mathrm{t}_{\text {tabel }}=1,734$

Ternyata $\mathrm{t}$ hitung lebih besar dari $\mathrm{t}$ tabel, maka Ho ditolak, artinya signifikan. Membuat Kesimpulan.

Karena $t_{\text {hitung }}=3,831$ lebih besar dari $t_{\text {tabel }}=1,734$, maka tolak Ho dan terima Ha. Dengan demikian terdapat pengaruh yang signifikan mata kuliah jurnalistik terhadap minat mahasiswa menjadi jurnalis.

\section{J. Diskusi dan Interpretasi}

Penelitian yang di laksanakan di Prodi KPI Fakultas Dakwah dan Komunikasi Islam Institut Agama Islam Darussalam (IAIDA) Blokagung Banyuwangi menggunakan pendekatan metode etic. Dalam arti bahwa peneliti mengumpulkan data dengan menetapkan terlebih dahulu konsep sebagai variabel-variabel yang berhubungan yang berasal dari teori yang sudah ada yang dipilih oleh peneliti. Kemudian variabel tersebut dicari dan ditetapkan indikator-indikatornya. Hanya dari indikator yang telah ditetapkan tersebut dibuat kuesioner, pilihan jawaban dan skor-skornya. Data yang diperoleh adalah berupa hasil penyebaran angket tentang Pengaruh Mata Kuliah Jurnalistik terhadap Minat Mahasiswa KPI IAIDA Blokagung Banyuwangi Menjadi Jurnalis, yang diisi oleh 20 mahasiswa KPI IAIDA Blokagung Banyuwangi Angakatan 2014. Adapun hasil pengujiannya adalah sebagai berikut:

Hipotesis Ha yang berbunyi: "Ada pengaruh yang signifikan antara Mata Kuliah Jurnalistik Terhadap Minat Mahasiswa KPI IAIDA Blokagung Banyuwangi menjadi Jurnalis" diterima. Hal ini di dasarkan pada: Pengaruh antara variabel mata kuliah jurnalistik (X) terhadap Minat Mahasiswa KPI IAIDA menjadi jurnalis (Y) dengan menggunakan uji korelasi Pearson Product Moment tergolong kuat. Sedangkan untuk menyatakan besar kecilnya kontribusi (sumbangan) variabel $\mathrm{X}$ terhadap $\mathrm{Y}$ atau koefisien determinan $=\mathrm{r}^{2} \mathrm{x} 100 \%=0,67$ $\mathrm{x} 100 \%=44,89 \%$, sisanya sebesar $55,11 \%$ ditentukan oleh variabel lain. 
Sedangkan untuk menguji signifikansi adalah dengan menggunakan rumus $t_{\text {hitung }}$ dan di dapat nilai $t_{\text {hitung }}=3,831$ dan $t_{\text {tabel }}=1,734$ yang berarti $t_{\text {hitung lebih besar dari }}$ $\mathrm{t}_{\text {tabel }}$ atau 3,831>1,734, yang berarti data tersebut signifikan. Atas dasar inilah maka disimpulkan bahwa hipotesis Ha yang diajukan diterima, sedangkan hipotesis Ho di tolak, yang berarti kesimpulannya adalah: “Ada pengaruh yang signifikan antara Mata Kuliah Jurnalistik Terhadap Minat Mahasiswa KPI IAIDA Blokagung Banyuwangi menjadi Jurnalis".

\section{K. Kesimpulan}

Berdasarkan hasil penelitian yang telah dilakukan dapat disimpulkan sebagai berikut: Ada pengaruh yang signifikan antara Mata Kuliah Jurnalistik Terhadap Minat Mahasiswa KPI IAIDA Menjadi Jurnalis, hal ini dapat dilihat dari uji korelasi Pearson Product Moment yang tergolong kuat. kuat. Sedangkan untuk menyatakan besar kecilnya kontribusi (sumbangan) variabel X terhadap $\mathrm{Y}$ atau koefisien determinan $=r^{2} \times 100 \%=0,67 \times 100 \%=44,89 \%$, sisanya sebesar $55,11 \%$ ditentukan oleh variabel lain. Sedangkan untuk menguji signifikansi adalah dengan menggunakan rumus $t_{\text {hitung }}$ dan di dapat nilai $t_{\text {hitung }}=3,831$ dan $t_{\text {tabel }}$ $=1,734$ yang berarti $t_{\text {hitung }}$ lebih besar dari $t_{\text {tabel }}$ atau 3,831 > 1,734, yang berarti data tersebut signifikan. Atas dasar inilah maka disimpulkan bahwa hipotesis $\mathrm{Ha}$ yang diajukan diterima, sedangkan hipotesis Ho di tolak, yang berarti kesimpulannya adalah: "Ada pengaruh yang signifikan antara Mata Kuliah Jurnalistik Terhadap Minat Mahasiswa KPI IAIDA Blokagung Banyuwangi menjadi Jurnalis"

\section{Saran}

Berdasarkan hasil dan pembahasan, kesimpulan diatas, maka di ajukan beberapa saran sebagai berikut:

1. Bagi Mahasiswa KPI IAIDA Blokagung Banyuwangi hendaknya lebih meningkatkan belajar dan menambah wawasan keilmuan tidak hanya di bangku kuliah serta lebih ditingkatkan lagi kedisiplinanya baik terkait absensi kehadiran maupun tugas-tugas dari dosen. 
2. Bagi dosen mata kuliah jurnalistik, selain memberikan teori hendaknya juga sering memberikan tugas-tugas terkait mata kuliah jurnalistik berupa praktek baik tulisan maupun praktek lapangan.

3. Bagi Lembaga Prodi KPI Fakultas dakwah dan Komunikasi Islam IAIDA hendaknya Sering megadakan pelatihan-pelatihan yang berbasis skill sebagai penunjang keilmuan dari mata kuliah.

\section{Daftar Pustaka}

Assegaf, Dja'far. 1991. Jurnalistik Masa Kini. Jakarta: Ghalia Indonesia.

Budyatna, M.A., Prof. Dr. Muhammad. 2014. Jurnalistik Teori dan Praktik. Bandung: PT. Remaja Rosdakarya.

Creswell, J. W. 2002. Educational Research: Planning, Conducing, and Evaluating Quantitative and QualitativebResearch. Upper Research, N. $\mathrm{J}$ : Merrill.

Fathoni, Prof, DR. H. Abdurrahmat, M.Si,. 2006. Metodologi Penelitian \& Teknik Penyusunan Skripsi. Jakarta: Rineka Cipta.

Gunadi, YS. 1998. Himpunan Istilah Komunikasi. Jakarta: Grassindo.

Mardalis, Drs. 2007. Metode Penelitian: Suatu Pendekatan Proposal. Jakarta: Bumi Aksara.

Mc Quail, Dennis. 1987. Teori Komunikasi Massa: Suatu Pengantar. Jakarta: Erlangga.

Riduwan, Drs, M.B.A. 2015. Pengantar Statistika. Bandung: Alfabeta.

SK, Patmono. 1990. Teknik Jurnalistik: Tuntutan Praktis untuk Jadi Wartawan. Jakarta: BPK Gunung.

Sugiyono. 2009. MetodePenelitian Administrasi, Bandung: Alfabeta.

------. 2006. Statistika untuk Penelitian, Bandung: Alfabeta.

Suharsimi, Arikunto Prof. Dr. 2010. Prosedur Penelitian, Yogyakarta: Rineka.

Sutrisno, Hadi. 2004. Metodologi Research. Yogyakara: Andi Offset.

Tim Penyusun Buku Kurikulum Tingkat Satuan Pendidikan Tinggi. 2009. Kurikulum Tingkat Satuan Pendidikan Tinggi. Surabaya: Kopertais IV Press.

Tim Penyusun Buku Pedoman Akademik IAIDA. 2016. Buku Pedoman Akademik program sarjana strata satu (S.1). Banyuwangi: Lembaga IAIDA.

Uchjana Effendy., M.A., Onong. 2003. Ilmu, Teori dan Filsafat Komunikasi. Bandung: PT. Citra Aditya Bakti.

Winkel W.S. 1986. Psikologi Pendidikan dan Evaluasi Belajar. Jakarta: PT. Gramedia.

Dokumen Prodi KPI IAIDA

http://www.gurupendidikan.com/pengertian-mahasiswa-menurut-para-ahlibeserta-peran-dan-fungsinya diakses pada 25 Mei 2017

http://www.jobdescriptionsample.org/id/2016/06/28/broadcast-news-analysts-jobdescription-accountability-sample-and-jobs. Di akses pada tanggal 29 Juni 2017 